\title{
The Two Sides of Online Learning Post Covid-19: Perspectives of International Students in China
}

\author{
Yohana Kifle Mekonen ${ }^{\mathrm{a}}$, Nweze Chiamaka Nneoma ${ }^{\mathrm{b}}$ \\ ${ }^{a}$ Kyohana24@yahoo.com \\ ${ }^{a}$ Faculty of Education, Southwest University \\ Tiansheng Road, Beibei,Chongqing, 400715, China \\ ${ }^{b}$ Chimaxesthy@gmail.com \\ Faculty of Education, Southwest University \\ Tiansheng Road, Beibei,Chongqing, 400715, China
}

\begin{abstract}
Online learning remains the best alternative during the Covid- 19 pandemic as keeping social distance was advocated. Recently, there has been recorded dramatic increase of using virtual class across the globe. The study aimed to explore the perceptions of international students regarding the online learning in China during Covid-19 pandemic. To bring this to an end, individual interviews and focus group discussion were employed on international students of selected university in China. Students' low engagement and participation, less interactive class, and network bandwidth problems were some of the challenges identified in the study. Accordingly, the study suggested several aspects that need careful consideration for effective online learning. Orientation and adequate training for instructors in addition to employing effective monitoring mechanisms were the highly recommended aspects. Furthermore, participants of the study stated some positive outcomes gained due to the participation of online learning; gaining of new digital skills and more self- regulation behavior were stated.
\end{abstract}

Keywords: online class, Covid-19, international students, perspectives

\section{Introduction}

Corona virus which lately called Covid- 19 is one of pathogens human coronaviruses (HCoVs) recognized firstly in city of Wuhan, Hubei province, China in December, 2019 (Paules, Marston, \& Fauci, 2020; Roy et al., 2020). The rapid evolving situation caused severe illness and fatality as the number of confirmed cases increased dramatically. On March 11, 2020 the World Health Organization (WHO) officially declared a global health emergency and pandemic (WHO, 2020). In response to the shocking incident, Public health officials of countries across the globe focused on alleviating its impact on social life and education through successful clinical trials and pharmaceutical procedures (Reimers, \& Schleicher, 2020). Hence, Social-distancing measures emerged as a primary and best intervention for slowing down the virus due to the unavailability of a potent vaccine (Sintema, 2020, Yan, 2020; Zhou, \& Li, 2020). Banning of public gathering as quick responsive measure took place (Paules, Marston, \& Fauci, 2020) which consequentially brought many inconveniences and triggered lot of changes in different private and public sectors (Viner, et al., 2020).

China declared immediate lockdown and applied social distance in practice at early stage (Fernandes, 2020). Noticeably, this intervention reduced the wave of new infection but also resulted in a heavy loss to the economic sector (Fernandez, 2020; Viner, et al., 2020), enormous inconvenience in education (Almanthari, Maulina, \& Bruce, 2020; Sintema, 2020) and led to intensified level of students' stress (Roy et al., 2020). Reimers, \& Schleicher (2020) explained "the restrictions caused by non-pharmaceutical interventions like social distancing have also impacted education at all levels, and will continue to do so for at least several months, as learners and teachers are unable to physically meet in the schools and universities" (p.3). This is to say that classroom teaching has ended without stopping learning and this created a large-scale, normal application of online education (Basilaia, \& Kvavadze, 2020; Sintema, 2020). 
An online class which is commonly used in higher institution was first developed as a new approach in the United States as the flexible opportunities to encourage learners to balance study with other activities (Sun, \& Chen 2016). Similarly, during the Covid-19, Chinese universities have been undergoing transition from physical classes to online education starting early spring 2020 (Bao, 2020, Huang et al., 2020; Zhou, \& Li, 2020). Thereby, the university under study engaged in demanding and intensive countermeasures for keeping the health of international students in one side and dealing the academic affairs in other side. This sudden shift of practice eventually caused many uncertainties and inconvenience for students and teachers in particular and for the education system in general irrespective of its benefits (Basilaia, \& Kvavadze, 2020, Naciri, Baba, Achbani, \& Kharbach, 2020; Radwan, \& Radwan, 2020). Covid-19 affects every step of higher educational institutions and will continue to impact future international students (Hope, 2020).

Therefore, the overarching research question leading the research investigation is; what are the perceptions of international students regarding the online learning in China during the Covid-19 pandemic?

\section{Literature Review}

\subsection{Online learning}

Online learning is an instructional experience aided by internet access (Huang et al., 2020). It "comprises a wide variety of programs that use the Internet within and beyond school walls to provide access to instructional materials as well as facilitate interaction among teachers and students" (Bakia, Shear,Toyama, \& Lasseter, 2012, p.5). The term is used interchangeably with in several research literatures as e- learning, online- education, distance education, blended learning, computer-based learning (Sun, \& Chen 2016; Quadri et al., 2017). Online educational courses in higher institutions occurred gradually with the initial objective of connecting teachers and students via correspondence distance (Mclsaac \& Gunawardena, 1996) and continued to integrate new and more innovative approach to meet the diversified needs of learners (Toquero, 2020). Not differently, Chinese universities started online education alterations for promoting open web of information since early 21 st century (Bao, 2020).

Recently study by Mulenga \& Marban (2020) indicated that, Covid-19 have been opened a substantial gate for digital learning across the globe. WeChat, QQ, and Dingtalk in China (Zhou, \& Li, 2020), online portal, TV School and Microsoft teams in Georgia (Basilaia, \& Kvavadze, 2020), Google Classrooms and WebQuest in Philippines (Toquero, 2020) and Facebook and WhatsApp social medias in Zambia (Sintema, 2020) has been using for facilitating online education. As different institutions used various types of online platforms, the modes of teaching are also diversified. Online learning take place using asynchronous or synchronous or combination of both, the former is known with no direct interaction and doesn't necessary need communication and the later happens in realtime which employed audio and video virtual conferencing (Basiliaia, \& Kvavadze, 2020; Brown, Schroeder, \& Eaton, 2016).

Several studies found the positive impact of online learning for both teachers and learners. The flexible nature of teaching mode that take place at any place and time (Corbeil \& Valdes-Corbeil, 2007) and fostering students selfregulated learning (Sha, Looi, Chen, \& Zhang, 2012) are among other benefits. Likewise, Finch \& Jacobs (2012) noted more convenience with less time and expenses for travel and high opportunity to interact with experts as the main advantages of online learning. In the same vein, You \& Kang (2014) indicated that online learning is more conducive for self-regulated student learning. Moreover, some studies have found that the use of information technology in addition to improving student performance, also help to reduce inequality in education (Tian, et al., 2020) and increases access at low expenses (Bakia, Shear, Toyama, \& Lasseter, 2012). Contradictory research by Rovai, Wighting \& Lui (2005) found out there is no significant difference in learning outcome of online versus traditional or face to face learning. In line with this, Crawford-Ferre \& Wiest (2012) stated online courses take more time for teaching than traditional courses. 


\subsection{Implementation of online learning in Covid-19}

To reduce human-to-human transmission of the Covid-19, stay-at-home regulations surfaced as an alternative but this equally caused anxiety and stress for students' learning (Bao, 2020; Toquero, 2020; Zhou, \& Li, 2020). Likewise, Brooks et al. (2020) stated the psychological impact of quarantine was wide ranging and substantial that can be long lasting. As a remedy, study by Toquero (2020) recommended that higher institutions should reinforce counseling and health services to support students afflicted by the pandemic trend and treat students' psychological health and academic achievement equally. Moreover, low students focus and engagement for online classes (Bao, 2020) and informal student and staff absenteeism (Viner, et al, 2020) which demands high attention for implementing effective online education were detected. In this regard, Bao (2020) identified reasonable pace of lesson according to students' keenness for effective delivering, adequate support and guidance, provision of immediate feedback, ensuring active participation and involvement of students as well as preparation of instructors in advance as effective strategies for online classes. In the same circle, study by Sun, \& Chen (2016), after reviewing a wide range of literature from different database regarding online learning came with the following findings. Wellorganized content to be taught, active interaction between learners and instructors, full readiness and preparation of instructors, formation of online learning community and various technological equipment as essential for effective online education. Hence, professional development as means of upgrading and enriching the existing knowledge and skills is essential in higher education institutions (Antil, 2017). Moreover, Sun, \& Chen (2016), advocate professional development concerning course planning, instruction, application as well as assessing as decisive for fruitful online learning.

\subsection{Challenges of online learning}

During the Covid-19 pandemic Almanthari, Maulina, \& Bruce (2020) stated e-learning has been implemented widely. It is supported by technologies such as the internet, TV broadcasting, phone, radio, and phone messaging or email communication. It was a quick responsive alternative in this era of Covid-19 where the notation shifted to working and learning from home (Bao, 2020; Toquero, 2020). Nevertheless, several challenges and problems exist that made its implementation ineffective somehow (Almanthari, Maulina, \& Bruce, 2020). Zhou, et al. (2020) advocated that, even though online education is becoming an important category of school education however it lacks practical application scenarios. Basilaia, \& Kvavadze (2020) stated that shifting to online education requires technological tools and accessibility of internet by which inadequate number of them in country side areas makes the process unfavorable. Similarly, PISA data of 2018 indicated that in some countries like Indonesia there are inadequate separate space and computers for students to study in home (Reimers, \& Schleicher, 2020).

Earlier study reported that in higher education many faculty members were unwilling to teach online courses (Crawford-Ferre \& Weist, 2012) as their respective institution offered insufficient support (Sun, \& Chen 2016). As the Covid-19 pandemic was a sudden incident, instructors faced numerous challenges as much expectation relied on them. Concerning faculty members; lack of exposure to online teaching, low preparation in advance as well as problems for dealing technological tools (Bao, 2020) can be listed. The same author mentioned some of the problems that existed regarding students were low attitude and readiness, low self- regulation, and lack of more conducive learning environment. Likewise, Toquero (2020) mentioned low preparation of several higher education institutions in Philippines as a major obstacle for online education implementation. Lack of conducive infrastructure and provision of accessible essential educational facilities for staffs and students with disabilities, problem of equity of network access and technological tools listed as problems faced by many countries (Reimers, \& Schleicher, 2020). Though students- centered approach to teaching is advocated as an interactive way of teaching, due to ineffective modes, methods and tools of online education, this target may not be reached (Sun, \& Chen 2016). Thus, there is a call for balancing of instruction and appropriate technological tools integrated with suitable content (Keengwe \& Kidd, 2010). 


\section{Theoretical framework}

There is no single complete and universal theory that fits online education (Picciano, 2017). However, Garrison, Anderson \& Archer (2000) developed a model for computer conferencing in higher education based on the assumption that learning occurs in a community that is made up of teacher and students which is known as "Community of Inquiry (CoI)". The model encompasses three presences; cognitive presence, social presence and teaching presence (Picciano, 2017; Rourke, \& Kanuka, 2009). All the presences are overlapping while cognitive presence is central concept (Garrison, Anderson, \& Archer, 2001). According to Garrison, Anderson \& Archer (2000), cognitive presence refers to resolution, triggering events which include applying of new ideas, connecting data and exchange of information. Social presence refers to participants' personal characters which are categorized as emotional expression that entails consistent and open communication and, teaching presence is communal responsibilities of tutors for instruction strategy, support and explicit teaching (Rourke, \& Kanuka, 2009). According to Picciano (2017), in an online mode of delivery, the three overlapping concepts have to be effectively monitored to ensure a successful instruction. Absence of one concept will disrupt the delivery process and the ultimate goal of the online instruction may not be realized (Armellini, \& De Stefani, 2016; Garrison, 2003). As countries and educational institutions are adopting the online mode of teaching, it is imperative for educators to address these overlapping constructs/concepts.

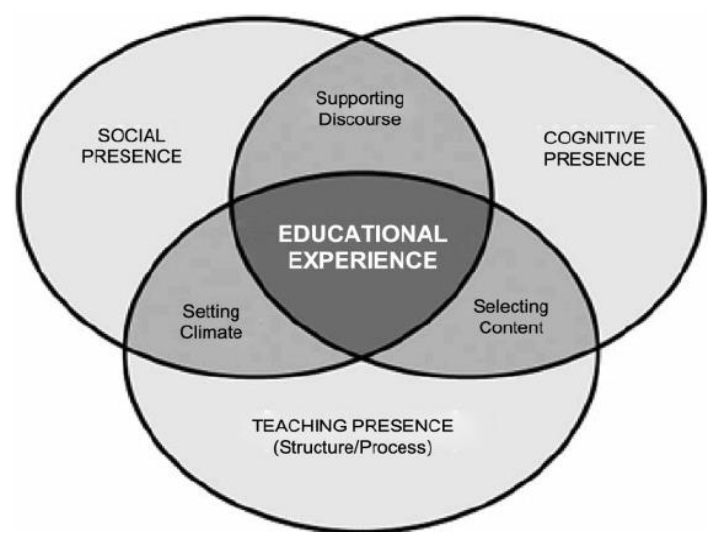

Fig. 1 Community of Inquiry model for effective educational experience, Garrison, Anderson, \& Archer (2000 p. 2).

\section{Methodology}

\subsection{Method}

A case study approach using a qualitative inquiry was used. According to Creswell (2017), the central aim of qualitative approach is to dig out detailed information, insight and understanding from participants who are close to the practical context and enables the researcher to do depth analysis of the problem that otherwise could be difficult; which was the principal objective of this study. Individual interviews and focus group discussion which are highly qualitative research approaches (Alshenqeeti, 2014) were used as data collection instruments. Focus group discussion is mostly used in round table format with group of people having something in common (Van Eeuwijk, \& Angehrn, 2017). Interviews as data collection instruments enables a researcher to widen the level of understanding for the area under study in a more realistic and flexible way (Alshenqeeti, 2014). Interview guide was used as "the interview guide allowed the interviewer to ask open-ended questions to encourage participants to expand their views on the subject matter" (Adarkwah, \& Zeyuan, 2020 p. 4).

\subsection{Data sources/ Participants}

Primary data are fresh and first hand so as commonly original. All the selected samples were international students both at home country and in China who attended online class. The study employed convenient sampling to choose the case university and purposeful sampling to choose participants as Creswell (2012) indicated in some studies 
using various sampling is essential. Convenient sampling is best used when limited time, resources and while participants are easily accessible (Elmusharaf, 2012; Etikan, Musa, \& Alkassim, 2016). Moreover, Creswell (2012) explained purposeful sampling in qualitative study when "researchers intentionally select individuals and sites to learn or understand the central phenomenon" (p.206). Purposeful sampling was used in order to cover varied students conditions to gain deep understanding. And the participants of the study were student staying in their country home, off campus students, and those staying on campus where also selected from three different international students dormitories and in different kinds of room (e.g. single, shared).

\subsection{Procedures}

Informed consent form detailing the purpose of the study was distributed to the chosen respondents of the study to gain their permission to conduct the study. Afterwards, the researchers conducted face-to-face and telephone interviews via social media app (WeChat) after participants were guaranteed data will be recorded and deleted to prevent any tracking. Moreover, the researchers informed pseudonyms would be used to every participant. English language was used in the whole data collection process. All the interviews and focus group discussion took place in a place that was suitable for the participants. Self- developed questions were developed after reviewing range of literatures in addition to some questions adopted from Reimers, \& Schleicher (2020) and contextualized carefully. The individual interviews and focus group discussion lasts an average time of fifteen minutes and one hour and thirty minutes respectively.

\subsection{Data Analysis}

Descriptive statistics in terms of frequencies were used to analyze the basic information of participants. Content analysis was used to analysis the data from both individual interviews and focus group discussion as it is a technique commonly and broadly used for qualitative research (Hsieh, \& Shannon, 2005; Neuendorf, \& Kumar, 2015). All the collected electronic data were transcribed by researchers manually. The process of coding was done twice. First broad themes were categorized and secondly similar sub- themes were careful merged together and some presented in the way originally stated.

\section{Findings and Discussions}

Table 1Participants basic information

\begin{tabular}{|c|c|c|}
\hline & & Frequency \\
\hline \multirow[t]{2}{*}{ Gender } & Male & 14 \\
\hline & Female & 8 \\
\hline \multirow[t]{3}{*}{ Program } & PHD & 8 \\
\hline & Masters & 4 \\
\hline & Bachelor & 10 \\
\hline \multirow{4}{*}{$\begin{array}{l}\text { Types of rooms } \\
\text { and place available }\end{array}$} & Single room & 2 \\
\hline & Shared room & 11 \\
\hline & Off campus & 4 \\
\hline & Home country & 5 \\
\hline \multirow{2}{*}{$\begin{array}{l}\text { Previous experience of online } \\
\text { class }\end{array}$} & Yes & 8 \\
\hline & No & 14 \\
\hline \multirow[t]{5}{*}{ Platforms used } & Dingtalk and Wechat & 14 \\
\hline & WeChat and QQ & 1 \\
\hline & Ten cent and ding talk & 4 \\
\hline & Ding talk and Zoom & 2 \\
\hline & Superstar and QQ & 1 \\
\hline \multirow[t]{5}{*}{ Teaching methods used } & Live broadcasting only & 3 \\
\hline & Combination of live broadcasting & \\
\hline & and resource package & 18 \\
\hline & Live broadcasting and group chat & \\
\hline & & 1 \\
\hline \multirow[t]{3}{*}{ Familiarity } & Self- study & 12 \\
\hline & Guidance by teachers & 7 \\
\hline & Colleagues & 3 \\
\hline Total & & 22 \\
\hline
\end{tabular}


According to table 1, the total number of the participants encompasses 22 international students of 14 male and 8 female. Among them, 18 were interviewed and 4 students participated in focus group discussion. Regarding the program of the participants, 8 of them were $\mathrm{PhD}, 4$ Masters, and 10 bachelor students. The participants of this research were diverse 5 from their country home, 4 are living off campus, and 13 stays on campus by which 2 out of them stays in single room while 11in a shared room. This purposeful sampling enabled the researchers for better understanding of the perceptions of different students at different location during the online learning. Regarding previous experience; 8 of the participants have had experience, while 14 students don't have any previous experience. The platform used varies 14 students used both Ding Talk and WeChat, 1 student used WeChat and QQ, 4 students used Ten cent and Ding Talk, 2 Ding Talk and zoom and 1 student used superstar and QQ. Ding Talk, WeChat, QQ, ten cents were the common tools used in China to handle online classes amongst ding talk was the most utilized app. "Ding Talk is a multi-terminal platform (e.g., PC, Web and mobile devices) for free communication and collaboration created by Alibaba Group for Chinese enterprises. It also supports the mutual transmission of files between mobile phones and computers" (Huang et al., 2020 p.11). To come up to the method used for 3 students was live broadcasting only while combination of live broadcasting and sending resource package for 18 students and for 1 student was live broadcasting and group chat. Concerning familiarity of the application used for online class 12 students stated they learnt by themselves, 7 and 3 students took guidance from teachers and colleagues respectively.

\subsection{Interview results}

Table 2 Qualitative themes and sub-themes from interview guide responses

\begin{tabular}{lcl}
\hline Themes & Sub themes \\
\hline Instructors & $\circ$ & Preparation \\
& $\circ$ & Technological skills \\
& $\circ$ & Class management and coordination \\
\hline University Preparation & $\circ$ & Technical and maintenance assistance \\
\hline Instructional time usage & $\circ$ & Influence of network and technical problems \\
& & \\
\hline Students' participation level & $\circ$ & Lack of motivation \& engagement \\
& $\circ$ & Participation merely depend on question and answers \\
\hline Positive Outcome & $\circ$ & Gain new technological knowledge and skills \\
& $\circ$ & Self- regulation and independent learning \\
& $\circ$ & Saves time for preparation and money for transportation \\
& $\circ$ & Academic skill development \\
\hline Challenges & $\circ$ & Low engagement and motivation \\
& $\circ$ & Less interactive class \\
& $\circ$ & Questions that remain unanswered, delay of feedback \\
& $\circ$ & Network bandwidth problems and high mobile data cost for \\
& $\circ$ & those back home \\
& $\circ$ & Difficulty to express gestures and emotions \\
& & \\
\hline Suggested/ possible solutions & $\circ$ & Orientation \\
& $\circ$ & Interactive class \\
& $\circ$ & Effective monitoring mechanism \\
& &
\end{tabular}

\subsubsection{Instructors' preparation}

To explore the perceptions of international students regarding the online learning, 18 students were interviewed. Drawing from the response there seem to be interconnectedness between instructors' preparation, skill of technological tools and efficient usage of instructional time. According to participants, most instructors were 
prepared content wise and some couldn't handle technological problems occur during the class. Consequently, at the time they seek technical assistance either from students or maintenance section of the university results inefficient instructional time usage. Most of the participants reported that instructors' age matters for efficient and effective online class, the younger instructors were more flexible and can easily handle problems encountered but the reverse was the case with the older instructors.

In case of some technical problems and inconvenience of network problems sometimes the instructor asked us to wait for ten minutes but if the instructor cannot handle the problem we cancel the class. Peter

If it's only one student who has difficulty the instructor ignores but if we are a lot, the instructor either look at other options or give us task to do in order to save the instructional time. - Angelina

In congruence, Zaharah \& Kirilova (2020) asserts that some teachers don't have exposure how to handle the application used for online classes which results to numerous difficulties and complications. Similarly, Almanthari, Maulina, \& Bruce (2020) stated online teaching in the pandemic era was an unexpected experience for most instructors whom had very limited experience before.

\subsubsection{Instructors' class management}

In terms of class coordination and management, participants responded usually instructors randomly and purposefully call students names to ensure whether or not students are listening attentively.

During online class, someinstructors have very good abilities tomanage the classvia live video broadcasting and record the whole class. Hence, this gives us opportunity to revise the recorded material. But unfortunately not all instructors did it. -Jolly

Mostly instructors were task oriented, only want to finish the planned lessons, and they do not use any interactive activities that make us engaged. They ask questions and use marks as means of rewarding or punishing for those who respond and don't respond at right time respectively. -Peter

In line with this, Huang et al. (2020) emphasized careful consideration should be given for making class interactive and living as several instructors fail to ensure cognitive and social presence of students while others challenged to find appropriate online resources aligned with the mode of context.

\subsubsection{University preparation}

Moreover, most of the students felt that the university preparation in providing technical and maintenance assistance was admirable as it was a sudden incident.

The university preparation was good; adequate facilities and provision of technical assistance for using online teaching is admirable. - Jolly

China was the leading country to deliver immense nationwide online education at the time of the pandemic (Huang et al., 2020).

\subsubsection{Students' participation level}

Participants were asked to what extent they were actively participated in online class where the responses of the majority were very low participation and engagement while very few stated as they had active participation. Some of them reported participation merely depends if instructors ask questions. Some students never experienced online class before (Zaharah \& Kirilova, 2020) which majority (63.3\%) of the participants of the study was their first time to attend online class. 
It was only at first I was motivated because we were under stress because of the pandemic, but lately I found the online class boring. You can do things that you cannot do in the face to face class. My attention switched to something else. - David

I can't say my participation was the same like face to face class, but my focus was only to complete the requested assignments. Furthermore, while we ask questions some of the instructors replied in a minute but some could not response at all. I feel anxious while the questions skipped. And messages have problems as we type our questions in the group platform, you have end to say a lot of things but you stated it in one sentence. - Jenifer

Roy et al. (2020) supported this, the pressure and frustration due to the pandemic leads to low engagement and motivation. Instructors should emphasize in choosing interactive methods of learning that elevate students' participation and engagement (Huang et al., 2020). Brooks et al. (2020) after reviewing of numerous research papers related to covid-19, found out frustration, pressure and anxiety were some of the psychological problems. Moreover, Garrison, \& Cleveland-Innes (2005) interaction was known as a fundamental aspect in online education. While Donlevy (2003) stated that, poor peer interaction impacts the process of learning adversely as social and emotional facets are as essential as the technical aspect. Similarly, "interaction and communication have been identified as key factors in the success of an online course, leading to enhanced student satisfaction and motivation" (Gilbert, 2015 p. 11).

\subsubsection{Positive Outcome of online class}

To investigate what positive outcomes students gained from attending online learning, several responses were listed. Gaining of new knowledge and skills regarding new applications and technological tools, self- regulation, independent learning, saves time for preparations and money for transport were amongst.

Online class fosters my self-organization behavior though I have been an organized person before. Because in face to face class always it has push effect but online class you just spent class time and everyone became offline and you don't know what your classmates are doing, just feel I had no one to ask and to push me. Hence, at first I don't know what to do I was left alone however, afterward I started to manage myself this fosters my self- regulated behavior. -Jenifer

Being independent is the behavior I developed as a result of online class, I feel there is no one to help me and no one to ask. Lately, it encourages me to study in my own. - Jenny

It helps to improve my personal skills in many aspects; fosters self-reflection of my own, and increase autonomy of my learning. - Samuel

Comparing to physical class online class don't have any pressure to wake up early, to take shuttle bus down to my college, just woke up I am right in class. -Martin

Development of more self- regulated behavior for learning was found among the advantages of online learning which is an essential aspect that entails motivation (You \&Kang, 2014). The same researchers define self- regulation enables learners to manage their own study time and environment for maximize their goals. Equally study by Quadri et al. (2017) supported that, e - learning saves time and money for preparation and transport as it is specified in the study. Likewise, distance learning promotes flexibility and freedom in terms of time and space (Chaney, 2001) and it is found online learning was outstanding option of teaching during the pandemic era (Adarkwah, 2020).

\subsubsection{Challenges}

Low engagement and participation, less interactive class, questions that remain unanswered, network bandwidth problems and high data cost for those in their home country, disturbance for students especially for those who are in 
their home country, off campus and students lived in shared room, difficulty to express gestures and emotions, delay in asking questions as typing takes time were among the most mentioned challenges.

The first challenge for me was low engagement and laziness, as I can join the class while I am on my bed. Moreover, I don't feel free to ask questions because I don't want to interrupt the instructor at the mid of the explanation tone. -David

Sometimes the quality of network and some background distraction, being lazy as I don't perform well comparing to previous and some students used network problem as excuse to skip class. -Angelina

My place sometimes was not convenient, as I live in shared room my roommates might be sleeping while I am attending class which I don't feel freedom to open my microphone whether to ask or answer. Additionally, we students have many differences. Some students' network is stronger than others, some have up graded digital tools while others not. However, most instructors consider those with loud voice as active students while others might be neglected -John

Communication mode was not convenient for interaction as it was typing used to express our concern. Thus, takes time the instructor already goes far, so bring he/ she back doesn't make me comfortable so I lose my focus. - William

Similarly study by Huang et al. (2020) stated though application of online learning was a better way, simultaneously many challenges were reflected globally. According to the researchers; unreliable internet network as mass of learners attended at the same time, difficulty of some instructors to deal with the digital tools, problems of being adaptive and encouraged in students' side can be mentioned. At the same time, study by Almanthari, Maulina, \& Bruce (2020) found out that internet access as a major among others barriers. Quadri et al. (2017) supported this low internet bandwidth and unsuitable infrastructure, lack of technical knowledge were some of the barriers reported in their study. Study by Viner, et al (2020) predicted that high rate of informal absenteeism both from students and staff side in the pandemic time. In the same vien, Quadri et al. (2017) \& Karkar-Esperat (2018) noted lack of students' motivation as a main barrier of e- learning.

\subsubsection{Possible/ Suggested solutions}

Among the most frequently mentioned suggested solutions were creating interactive class, effective class monitoring mechanisms as well as reduction of lecture time and content.

Marking scheme via attendance and participation affect our grades. However, some of students have strong network by which the instructors considered them as serious students while other are online but with weak internet quality which sometimes regarded as uninterested. Therefore, instructors should give careful consideration. - John

If more online video conferences modes used would be better for interactive learning as I found difficult to express myself through writing. - Simon

Almanthari, Maulina, \& Bruce (2020), revealed assessment mechanisms has been a challenge for teachers in the elearning time. Huang et al. (2020) supported the time and assessment modes should be flexible and digital resources for learning should be chosen appropriately and aligned with online learning. Study by Malkawi, Bawaneh, \& Bawa'aneh, (2020) suggested technical support and provision of adequate training both for instructors and students for better e- learning process.

\subsection{Focus Group Discussion}

A focus group discussion was held using 4 students to share their concerns as well as to identify strategies to improve the online classes. Overall, their response was similar from the interviewed participants. Nevertheless, there were some unique responses regarding teachers' management and possible improvement mechanisms. 
We gain a lot. As we will go for employment in not distant future, it would help us how to deal with online job interview, virtual conferences and presentations. -Monica

Some of the instructors I don't think they had prior experience of online class as they face several technical problems, they don't know well the app we used, which method to choose though the app have a lot of options. Not all teachers were ready. There was time we stopped class for some time as the instructors said couldn't use online class. Age matters as younger people can learn how to use technology fast. Moreover, we are more responsible for our studies. Some instructors asked us to open our camera and to show up our face which was not a good practice for us as doctoral students. Adams

Social life which makes the class environment living was missed in online learning. It's only the teacher teach and that's all. Moreover, we learnt a lot from instructors experience and peers discussion as we have diverse educational background thus we couldn't be beneficial. - James

No matter you are good student or not even if you like learning your participation would not be the same as traditional class. Here, language becomes a barrier sometimes you would ask the question, the instructors will not get clearly and vice versa. And also it was not the internet connectivity a problem, the challenge was the quality of network, unstable and had some interruption. The university and the faculty they did their best, but still depend on the instructor and students. The university can put everything in a place. At the center of this is orientation, if there was induction for instructors and orientation for students it might help the instruction to go smoothly and effectively. - Henry

Reimers, \& Schleicher (2020) support orientation regarding utilization of tools and practices is important for distance education as some countries like Singapore are progressing well to equip teachers for such fate.

\section{Strategies for effective online classes}

For creating interactive online instruction and ensuring quality of learning experience, understanding the interconnectedness of the three presences i.e. cognitive, social and teaching presence discussed in theoretical framework to build a determined community of inquiry is vital (Garrison, \& Cleveland-Innes, 2005).

\subsection{Cognitive presence}

Cognitive presence is the extent of constructing meaning and applying of new skills of those in circle of community of inquiry (Garrison, Anderson, and Archer, 2000) through facilitation of "critical reflection and discourse" (Garrison, 2003). The researcher asserted understanding of cognitive presence is important for profound and worthy educational experience and outcome. Similarly, Brown, Schroeder, \& Eaton (2016) stated instructors should put more emphasizes for creating an enabling class environment for cognitive presence that promotes open discussion and healthy interaction. Hence, creating dynamic online learning demands instructors to nurture various methods that promote active students participation and feeling of community (Sharoff, 2019). Faculty members need to be educated regarding instructional approaches that suitable for online learning (Kowalczyk, 2014) as they are at the center of the online instruction process (Bao, 2020). Crawford-Ferre \& Weist (2012) advocated training regarding how to stimulate cooperation with students, communicating high expectation, adapting online platforms, choosing appropriate teaching approaches should be given. Cognitive presence is facilitated by consistent communication as it enables learners to develop concepts (Kanuka, \& Garrison, 2004). Well stated standards and expectation have a profound impact for online learning (Sharoff, 2019). Minor training for instructors regarding building interactive online learning through contents to be instructed and provision of regular and timely feedback is essential (Mann, 2014). 


\subsection{Social presence}

Social presence is defined as "the ability of participants in a community of inquiry to project themselves socially and emotionally, as 'real' people (i.e. their full personality), through the medium of communication being used" (Garrison, Anderson \& Archer, 2000, p. 13). Interaction in online learning represents the connectedness between instructor- student, student- student, student-content (York, \& Richardson, 2012). In live broadcasting class should be established in a best way that reinforces interactions and develop community of inquiry (Bower, 2016). Reducing the feeling of psychological isolation occurs as time when students unable to see the facial expression of their instructors and colleagues is essential (Young, \& Bruce, 2011) which is stated as a challenge for building social presence, absence of visual signs (Garrison, Anderson \& Archer, 2000). According to Brown, Schroeder, \& Eaton (2016) instructor should offer visual help through choosing a mode of online learning that enables all the participants to see each other. Similarly Garrison, Anderson \& Archer (2000) underlined firm knowledge, ability, expertise, responsibility, motivation and duration of media usage are essentials for communication setting that explicitly impact the development of social presence.

\subsection{Teaching presence}

Teaching presence is a glue that bind the other two presences; cognitive and social. Here presence of teachers is a decisive for creating an effective community of inquiry and instruction (Garrison, Anderson \& Archer, 2000). Teaching presence relates to strategy, facilitation and learning (Akyol, \& Garrison, 2008). In computer based conference it was found that, instructors' behavior impacted the activity and encouragement of students (Tagg \& Dickinson, 1995). Therefore, as Garrison, Anderson \& Archer (2000) stated some aspects teachers need to give attention; balancing content to be taught, fostering of discussion leading skills and effective moderating communication abilities were some. According to France et al. (2006) student monitoring in an online class can be handle through utilization of trace annotation that can help students to better interpret the traces recording during the session, they can as well be monitored by the use of visualization tools such as dash-boards. In the same vein, instructors should study their students' inclination, strengths and weakness so as to establish an engaging learning atmosphere. Juan, Daradoumis, Faulin, \& Xhafa (2009) developed and verified data system which they called Student Activity Monitoring using Overview Spreadsheets (SAMOS). This model "facilitates the automatic generation of weekly monitoring reports derived from data contained in server log files" (p. 53). According to the model, the collected reports online instructors' gains insight concerning students' activity which provides immediate and simple identification of students that leads to provision of timely feedback and quick academic support. Moreover, initiate teacher- led and student- centered discussion with clearly stated expectation and guidelines is advisable strategy (Brown, Schroeder, \& Eaton, 2016).

\section{Conclusion and Recommendation}

The present study tried to explore the perceptions of international students regarding the online learning in China during the Covid- 19 pandemic. According to the participants who attended online learning, it was a best alternative for the sudden incident that secures health safely as concurrently stated by Malkawi, Bawaneh, \& Bawa'aneh (2020). The study also indicated some of positive outcomes of the online class. Fostering technological skill and knowledge, promotion of self- regulation and save time and money were the most repeatedly mentioned. Simultaneously, the study revealed several challenges encountered to international students. Students low engagement and motivation, less interactive class, network bandwidth problems and difficulty to express gestures and emotions. In addition, inefficient use of instructional time and difficulty to deal with the digital tools were shown. Hence for more effective learning the study came with the following recommendations aligned with the theoretical framework. Provision of orientation and adequate training for instructors, aligning of time, content and methods as well as monitoring mechanism needs careful consideration. Quadri et al. (2017) found out inadequate technological skills and insufficient training negatively impact self-confidence of instructors and leads to ill elearning implementation. Accordingly Malkawi, Bawaneh, \& Bawa'aneh (2020) recommend training to all involved 
in the learning process is essential. Likewise, education sectors need to ensure the quality and accessibility of network bandwidth for effective online classes and increasing the internet bandwidth as a remedy for frequent interruptions as vast of online education occurred at the same time (Huang et al., 2020).

\section{Future Research}

The study took place in a particular university in China as researchers cannot travel to other place apart from their university due to the pandemic at the time of data collection. Therefore, the findings of the study may not better explain to the situation of other universities. Additionally the study only employed qualitative approach via students' interview and focus group discussion. Hence, a wide study with large sample size and different research approaches is recommended. Moreover including multiple sources of data is suggested for understanding the situation through different angle to ensure triangulation of data.

\section{References}

Adarkwah, M. A. (2020). "I'm not against online teaching, but what about us?". ICT in Ghana post Covid-19. Education and Information Technologies, 1-21.

Adarkwah, M. A., \& Zeyuan, Y. (2020). Perceptions of the Effect of an EAP Course on English Self-Efficacy and English Proficiency: Voices of International Students in China. World Journal of English Language, 10(2), 1-17.

Akyol, Z., \& Garrison, D. R. (2008). The development of a community of inquiry over time in an online course: Understanding the progression and integration of social, cognitive and teaching presence. Journal of Asynchronous Learning Networks, 12, 3-22.

Almanthari, A., Maulina, S., \& Bruce, S. (2020). Secondary School Mathematics Teachers' Views on E-learning Implementation Barriers during the COVID-19 Pandemic: The Case of Indonesia. Eurasia Journal of Mathematics, Science and Technology Education, 16(7), em1860.

Alshenqeeti, H. (2014). Interviewing as a data collection method: A critical review. English linguistics research, 3(1), 39-45.

Antil, N. (2017). Professional Development of Teachers in Higher Education. Research Journal of Humanities and Social Sciences, 8(3), 311315 .

Armellini, A., \& De Stefani, M. (2016). Social presence in the 21st century: An adjustment to the Community of Inquiry framew ork. British Journal of Educational Technology, 47(6), 1202-1216.

Bao, W. (2020). COVID-19 and online teaching in higher education: A case study of Peking University. Human Behavior and Emerging Technologies, 2(2), 113-115.

Bakia, M., Shear, L., Toyama, Y., \& Lasseter, A. (2012). Understanding the Implications of Online Learning for Educational Productivity. Office of Educational Technology, US Department of Education.

Basilaia, G., \& Kvavadze, D. (2020). Transition to online education in schools during a SARS-CoV-2 coronavirus (COVID-19) pandemic in Georgia. Pedagogical Research, 5(4), 1-9.

Brooks, S. K., Webster, R. K., Smith, L. E., Woodland, L., Wessely, S., Greenberg, N., \& Rubin, G. J. (2020). The psychological impact of quarantine and how to reduce it: rapid review of the evidence. The Lancet.

Brown, B., Schroeder, M., \& Eaton, S. E. (2016). Designing Synchronous Online Interactions and Discussions. Proceedings of the IDEAS: Designing for Innovation, pp. 51-60. Calgary, Canada: University of Calgary.

Corbeil, J. R., \& Valdes-Corbeil, M. E. (2007). Are you ready for mobile learning?. Educause Quarterly, $30(2), 51$.

Chaney, E. G. (2001). Web-based instruction in a rural high school: A collaborative inquiry into its effectiveness and desirability. NASSP Bulletin, 85(628), 20-35.

Crawford-Ferre, H. G., \& Wiest, L. R. (2012). Effective online instruction in higher education. The Quarterly Review of Distance Education, 13(1), 11-14.

Creswell John, W. (2012). Planning, Conducting, and Evaluating Quantitative and Qualitative Research. Lincoln: University of Nebraska Daulat Purnama.

Donlevy, J. (2003). Teachers, technology and training: Online learning in virtual high school. International Journal of Instructional Media, 30(2), 117.

Elmusharaf, K. (2012). Qualitative sampling techniques: training course in sexual and reproductive health research. RCRU/UMST: Geneva.

Etikan, I., Musa, S. A., \& Alkassim, R. S. (2016). Comparison of convenience sampling and purposive sampling. American journal of theoretical and applied statistics, 5(1), 1-4.

Fernandes, N. (2020). Economic effects of coronavirus outbreak (COVID-19) on the world economy. Available at SSRN 3557504.

Finch, D., \& Jacobs, K. (2012, September). Online education: Best practices to promote learning. In Proceedings of the human factors and ergonomics society annual meeting, 56(1), 546-550.

Garrison, D. R., Anderson, T., \& Archer, W. (2000). Critical inquiry in a text-based environment: Computer conferencing in higher education model. The Internet and Higher Education, 2(2-3), 87-105. 
Garrison, D. R. (2003). Cognitive presence for effective asynchronous online learning: The role of reflective inquiry, self-direction and metacognition. Elements of quality online education: Practice and direction, 4(1), 47-58.

Garrison, D. R., Anderson, T., \& Archer, W. (2001). Critical thinking, cognitive presence, and computer conferencing in distance education. American Journal of distance education, 15(1), 7-23.

Garrison, D. R., \& Cleveland-Innes, M. (2005). Facilitating cognitive presence in online learning: Interaction is not enough. The American journal of distance education, 19(3), 133-148.

Gilbert, B. (2015). Online learning revealing the benefits and challenges.

Huang, R. H., Liu, D. J., Tlili, A., Yang, J. F., \& Wang, H. H. (2020). Handbook on facilitating flexible learning during educational disruption The Chinese experience in maintaining undisrupted learning in COVID-19 Outbreak. Beijing: Smart Learning Institute of Beijing Normal University.

Hope, J. (2020). Be aware of how COVID-19 could impact international students. The Successful Registrar, 20(3), 1-8.

Hsieh, H. F., \& Shannon, S. E. (2005). Three approaches to qualitative content analysis. Qualitative health research, 15(9), 1277-1288.

Juan, A. A., Daradoumis, T., Faulin, J., \& Xhafa, F. (2009). SAMOS: a model for monitoring students' and groups' activities in collaborative elearning. International Journal of Learning Technology, 4(1-2), 53-72.

Kanuka, H., \& Garrison, D. R. (2004). Cognitive presence in online learning. Journal of Computing in Higher Education, 15(2), 21.

Keengwe, J., \& Kidd, T. T. (2010). Towards best practices in online learning and teaching in higher education. MERLOT Journal of Online Learning and Teaching, 6(2), 533-541.

Malkawi, E., Bawaneh, A. K., \& Bawa'aneh, M. S. Campus Off, Education On: UAEU Students' Satisfaction and Attitudes Towards E-Learning and Virtual Classes During COVID-19 Pandemic.

Mclsaac, M. S., \& Gunawardena, C. N. (1996). The handbook of research for educational communications and technology. Mahwah, NJ: Lawrence Erlbaum Associates.

Mulenga, E. M., \& Marbán, J. M. (2020). Is COVID-19 the Gateway for Digital Learning in Mathematics Education?. Contemporary Educational Technology, 12(2), ep269.

Naciri, A., Baba, M. A., Achbani, A., \& Kharbach, A. (2020). Mobile learning in Higher education: Unavoidable alternative during COVID19. Aquademia, 4(1), ep20016.

Neuendorf, K. A., \& Kumar, A. (2015). Content analysis. The international encyclopedia of political communication, 1-10.

Karkar-Esperat, T. M. (2018). International graduate students' challenges and learning experiences in online classes. Journal of International Students, 8(4), 1722-1735

Paules, C. I., Marston, H. D., \& Fauci, A. S. (2020). Coronavirus infections-more than just the common cold. Jama, 323(8), 707-708.

Picciano, A. G. (2017). Theories and frameworks for online education: Seeking an integrated model. Online Learning, 21(3), 166-190.

Quadri, N. N., Muhammed, A., Sanober, S., Qureshi, M. R. N., \& Shah, A. (2017). Barriers effecting successful implementation of e-learning in Saudi Arabian universities. International Journal of Emerging Technologies in Learning (iJET), 12(06), 94- 107.

Radwan, A., \& Radwan, E. (2020). Social and economic impact of school closure during the outbreak of the COVID-19 pandemic: A quick online survey in the Gaza Strip. Pedagogical Research, 5(4)1-5.

Reimers, F. M., \& Schleicher, A. (2020). A framework to guide an education response to the COVID-19 Pandemic of 2020. OECD. Retrieved April, 14, 2020.

Rourke, L., \& Kanuka, H. (2009). Learning in communities of inquiry: A review of the literature. International Journal of E-Learning \& Distance Education/Revue internationale du e-learning et la formation à distance, 23(1), 19-48.

Rovai, A. P., Wighting, M. J., \& Liu, J. (2005). School climate. Quarterly Review of Distance Education, 6(4), 361-374.

Roy, D., Tripathy, S., Kar, S. K., Sharma, N., Verma, S. K., \& Kaushal, V. (2020). Study of knowledge, attitude, anxiety \& perceived mental healthcare need in Indian population during COVID-19 pandemic. Asian Journal of Psychiatry, 102083.

Sintema, E. J. (2020). E-Learning and Smart Revision Portal for Zambian primary and secondary school learners: A digitalized virtual classroom in the COVID-19 era and beyond. Aquademia, 4(2), ep20017.

Sha, L., Looi, C. K., Chen, W., \& Zhang, B. H. (2012). Understanding mobile learning from the perspective of self-regulated learning. Journal of Computer Assisted Learning, 28(4), 366-378.

Sun, A., \& Chen, X. (2016). Online education and its effective practice: A research review. Journal of Information Technology Education, (15),157-190

Tagg, A. C., \& Dickinson, J. A. (1995). Tutor messaging and its effectiveness in encouraging student participation on computer conferences. Journal of Distance Education, 10, 33-56.

Tian, H., Liu, Y., Li, Y., Wu, C. H., Chen, B., Kraemer, M. U., ... \& Wang, B. (2020). An investigation of transmission control measures during the first 50 days of the COVID-19 epidemic in China. Science, 368(6491), 638-642.

Toquero, C. M. (2020). Challenges and opportunities for higher education amid the COVID-19 pandemic: The Philippine context. Pedagogical Research, 5(4), 1-5.

Van Eeuwijk, P., \& Angehrn, Z. (2017). How to... Conduct a Focus Group Discussion (FGD). Methodological Manual.

Viner, R. M., Russell, S. J., Croker, H., Packer, J., Ward, J., Stansfield, C., ... \& Booy, R. (2020). School closure and management practices during coronavirus outbreaks including COVID-19: a rapid systematic review. The Lancet Child \& Adolescent Health. 
World Health Organization. (2020). Statement on the second meeting of the International Health Regulations (2005) Emergency Committee regarding the outbreak of novel coronavirus (2019-nCoV).

Yan, Z. (2020). Unprecedented pandemic, unprecedented shift, and unprecedented opportunity. Human Behavior and Emerging Technologies, 2(2), 110-112.

You, J. W., \& Kang, M. (2014). The role of academic emotions in the relationship between perceived academic control and self-regulated learning in online learning. Computers \& Education, 77, 125-133.

Zaharah, Z., Kirilova, G. I., \& Windarti, A. (2020). Impact of corona virus outbreak towards teaching and learning activities in Indonesia. SALAM: Jurnal Sosial dan Budaya Syar-i, 7(3), 269-282

Zhou, P., Yang, X. L., Wang, X. G., Hu, B., Zhang, L., Zhang, W., \& Chen, H. D. (2020). A pneumonia outbreak associated with a new coronavirus of probable bat origin. nature, 579(7798), 270-273. 